\title{
Quality analysis of fresh and dried mangoes
}

\section{S. Arendt ${ }^{\mathrm{a}, \mathrm{b}}$, K. Jödicke ${ }^{\mathrm{a}}$, W. Hofacker ${ }^{\mathrm{a}}$, W. Speckle ${ }^{\mathrm{b}}$}

${ }^{a}$ Institute of Applied Thermo- and Fluiddynamics, HTWG Konstanz University of Applied Sciences.

${ }^{\mathrm{b}}$ Environmental Analysis Laboratory, University of Applied Sciences Ravensburg-Weingarten

*E-mail of the corresponding author: katrin.joedicke@htwg-konstanz.de

\begin{abstract}
Organic acids, sugar and colour define the quality and the taste of mangoes. The quality deteriorates during drying on a single-layer-dryer. Quality losses can be reduced by using drying parameters that influence the quality less. In this research, the contents of ascorbic acid, organic acids and sugar as well as colour changes and shrinkage are analysed. Analyses are carried out at different temperatures, dew point temperatures and air velocities using HPLC, IC and UV/Vis- spectrometry. The quality criteria showed the lowest changes at a temperature of $60^{\circ} \mathrm{C}$, dew point temperature of $20^{\circ} \mathrm{C}$ and an air velocity of $0.9 \mathrm{~m} / \mathrm{s}$.
\end{abstract}

Keywords: organic acids; sugars; colour; shrinkage; thin-layer-dryer. 


\section{Introduction}

The world's population is projected to reach nine billion by 2050. It is expected that the number of people suffering from chronic undernourishment (1 billion in 2010) will therefore increase significantly by 2050. Due to this fact, it is vital to make the food available more useful during production. In developing and transition countries, the main focus should be on reducing post-harvest losses [1]. These losses can be avoided if the shelf life of the products is extended. In order to extend the shelf life of the investigated products, it is necessary to influence the microbial population by changing the conditions in the products; so microorganisms cannot grow and reproduce. One method to make agricultural products more durable is drying [2]. During drying, the agricultural products lose water and the living conditions for microorganisms become increasingly harsher. But during drying, the products undergo a loss of quality, e.g. changes in taste, degradation of vitamins and temperature sensitive acids and change in colour. Optimal drying parameters can reduce such quality losses and preserve the essential quality criteria of the investigated agricultural products. In this study, the content of ascorbic-, citric- and malic acid as well as the sugar content of fresh and dried mangoes are analysed. Analyses are carried out on mangoes dried with an experimental single-layer-dryer described by ARENDT using HPLC, IC and UV/Vis instruments [3].

\section{Materials and Methods}

The mango plant originates from the tropics of India and Burma. Its edible pulp is yellow tor orange-red and is protected by a leathery shell, which in ripe state has a green to orangered colour, depending on the variety. [4]

\subsection{Quality Criteria of Mangoes}

Because humans and animals have lost their ability to synthesize ascorbic acid out of carbohydrates, it is essential to ingest ascorbic acid within their diet. Ascorbic acid is an important compound in all living organisms and maintains metabolic functions. The best way to reach the daily necessity of 250 to $300 \mathrm{mg}$ is by consuming fruits and vegetables. Ascorbic acid acts like an antioxidant against free radicals and can reduce cancer risks and risk for arteriosclerosis [5, 6, 7]. Environmental conditions like light, temperature, oxygen, cations, trace elements and the $\mathrm{pH}$-value can influence the ascorbic acid content in fruits [5, 7]. Therefore the content of ascorbic acid in mangoes can vary from one fruit to another. The stability of ascorbic acid in food products or an aqueous medium depends on different ambient conditions. Factors lowering the content of ascorbic acid include light, oxygen, high temperature, alkaline $\mathrm{pH}$-values, enzymatic reactions and catalytically active metal ions [7, 8]. Citric acid is found in every living cell because it is produced as an intermediate in the citric acid cycle and is required for energy generation. Like other antioxidants, it is able to conserve fat, colours, flavors and vitamins in food. Furthermore, it is able to 
complex heavy metals and acts like an important inhibitor against uroliths [9, 10, 11]. Together with malic acid, citric acid contributes significantly to the flavor of fruits and vegetables [12]. The riper the fruit is, the lower its content of malic acid [12]. Malic acid also has a supportive effect on antioxidants and therefore inhibits enzymatic browning in truncated or injured fruits and vegetables [13]. Malic acid occurs in L- and D-form, but only L-malic acid is present in nature. Malic acid is found in all living cells because it also appears as an intermediate in the citric acid cycle and is required for energy generation [13]. The primary sugars available in mangoes are sucrose, glucose and fructose. Together with polyphenols and the organic acid content, the sugar content defines the taste of fruits and vegetables $[14,15]$. The carbohydrates are the energy providers for the human body and also serve as construction material of cells. [7, 16]

\subsection{Sample Preparation and Experimental Set-up}

Mangoes were purchased at a local supplier in Konstanz, Germany. For analysis fresh and dried mangoes were frozen in liquid nitrogen and pulverized in a Moulinex mill. In each series of experiments, the mangoes were dried in a laboratory single-layer-dryer. For the drying process, the through flow principle was applied with air temperatures of $40^{\circ} \mathrm{C}, 60^{\circ} \mathrm{C}$, $80^{\circ} \mathrm{C}$ and $94^{\circ} \mathrm{C}$, dew point temperatures of $5^{\circ} \mathrm{C}, 10^{\circ} \mathrm{C}, 20^{\circ} \mathrm{C}, 30^{\circ} \mathrm{C}$ and $37^{\circ} \mathrm{C}$ and air velocities of $0.6 \mathrm{~m} / \mathrm{s}, 0.9 \mathrm{~m} / \mathrm{s}, 1.2 \mathrm{~m} / \mathrm{s}$ and $1.4 \mathrm{~m} / \mathrm{s}$. The homogenized samples were extracted for measuring quality criteria.

\subsubsection{Ascorbic Acid Extraction}

The fresh and dried mangoes were prepared according to the European Standard EN 14130 [18]; diluted meta-phosphoric acid was used to extract the samples. This suspension was then filtered. A certain amount of the filtrate was diluted with an L-cysteine solution, and adjusted to a pH-value between 7.0 and 7.2. The solution was then stirred for a defined time and set to a value between 2.5 and 2.8 on the $\mathrm{pH}$-scale. Prior to injection to the HPLC ultrapure water was added to the solution until a defined volume was reached. Furthermore, the samples were filtered with a $0.45 \mu \mathrm{m}$ filter to prevent pollution of the RP- (reversed phase-) column [18] before the injection to the HPLC.

\subsubsection{Organic Acid Extraction}

The fresh and dried mangoes were diluted in ultrapure water and extracted for 30 minutes in an ultrasonic bath. Then the samples were filtered and subsequently injected to the ICsystem. Prior to IC analysis the filtrates were filtered through a $0.45 \mu \mathrm{m}$ filter to prevent the organic acid column (ion-exclusion chromatography (IEC)) from pollution.

\subsubsection{Sugar Extraction}

For sugar extraction, fresh and dried mango samples were diluted with ultrapure water. The samples were extracted for 10 minutes on a magnetic stirrer. Then the diluted samples were 
filtered and processed like described in the manual of the enzymatic test of R-BIOPHARM AG. Following this enzyme kit, the content of sucrose, D-glucose and D-fructose were measured using an UV/Vis-spectrometer. Samples were prepared in a way that enables the determination of D-glucose content before and after the enzymatic hydrolysis of sucrose. Subsequently, the content of D-fructose was determined. [19]

\subsubsection{Experimental}

The ascorbic acid extracts of fresh and dried mango samples were analysed by an HPLC System (1260 Infinity, AGILENT TECHNOLOGIES, INC.). The used column was a LiChrosher (5 $\mu$ C18 100A; 4.0 x $250 \mathrm{~mm}$ ). The ascorbic acid (L(+)-ascorbic acid) was analysed by isocratic elution using an eluent consisting of ultrapure water with $\mathrm{KH}_{2} \mathrm{PO}_{4}$ and methanol with N-cetyl-N,N,N-trimethyl-ammonium bromide according to the European Standard EN 14130. Detection of the ascorbic acid was carried out with a diode-arraydetector at a wavelength of $254 \mathrm{~nm}$. [18] The extracts of the organic acids were analysed using the METROHM ion chromatograph 883 Basic IC plus. The sample components were separated on a chromatographic ion-exclusion chromatography (IEC) column, Organic Acid 6.1005.200 from METROHM GmbH \& Co. KG (particle size of $9 \mu \mathrm{m}$, length of $250 \mathrm{~mm}$, diameter of $7.8 \mathrm{~mm}$ ). As mobile phase acetone diluted with $0.5 \mathrm{mmol} / \mathrm{L} \mathrm{H}_{2} \mathrm{SO}_{4}$ was used (standard eluent) [20]. A suppressor cell was placed prior to the conductivity detector. Sugar content analysis of the extracted and prepared mangoes was done using an UV/Vis spectrometer at a fixed wavelength of $340 \mathrm{~nm}$ [19].

\section{Results and Discussion}

The drying process was carried out using an experimental approach, which was developed by a Design of Experiment (DoE) software. A response surface plan with central composite design was created. Air temperatures $\left(40^{\circ} \mathrm{C}, 60^{\circ} \mathrm{C}, 80^{\circ} \mathrm{C}, 94^{\circ} \mathrm{C}\right)$, dew point tempera-tures $\left(5^{\circ} \mathrm{C}, 10^{\circ} \mathrm{C}, 20^{\circ} \mathrm{C}, 30^{\circ} \mathrm{C}, 37^{\circ} \mathrm{C}\right)$ and air velocities $(0.6 \mathrm{~m} / \mathrm{s}, 0.9 \mathrm{~m} / \mathrm{s}, 1.2 \mathrm{~m} / \mathrm{s}, 1.4 \mathrm{~m} / \mathrm{s})$ were used as variable parameters. The aim was to determine the influence of these factors on the quality of the dried samples (mango slices with an initial thickness of $0.4 \mathrm{~cm}$ ). For fresh mangoes, almost constant ascorbic acid contents were detected. Small variations in the contents would be due to natural variations of the fresh product. Fig. 1 shows the retention of ascorbic acid in dried mangoes plotted against the drying temperature.

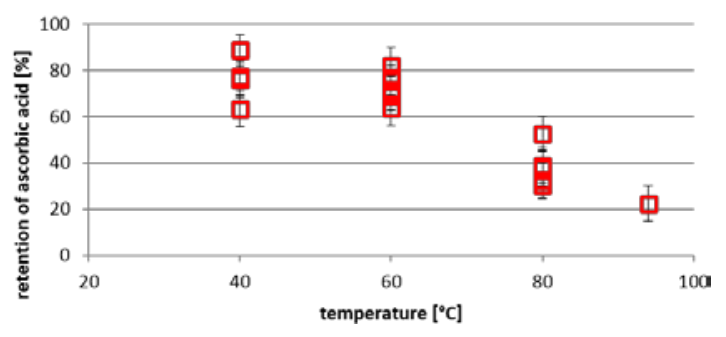

Fig. 1 Retention of ascorbic acid in mangoes 
As shown in fig. 1 , the content of ascorbic acid decreases due to drying (retention $<100 \%$ ). The degradation level increases with increasing drying temperatures. This was expected because the ascorbic acid decomposes during drying at high temperatures and in the presence of oxygen [8]. The concentration of citric acid in dried mangoes (fig. 2) shows nearly the same tendency as the concentration of ascorbic acid. It decreases as the drying temperature increases, and thus, during shorter periods of drying times.
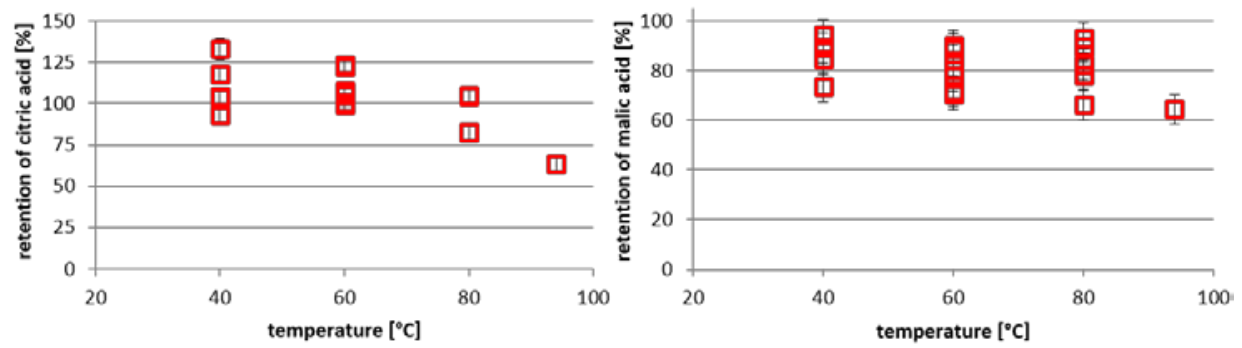

Fig. 2 Retention of organic acids in mangoes

In the case of the malic acid (fig. 2) in dried mangoes, the results showed some variations when compared to those of ascorbic and citric acid. The trend of degradation with increasing drying temperatures can only be slightly noticed. It can be concluded that malic acid is reduced during drying, but remains nearly independent of the drying temperature. Fig. 3 shows the content of the three main sugars (glucose, fructose, sucrose) in mangoes. As shown in fig. 3 (left), the content of glucose increases during drying.
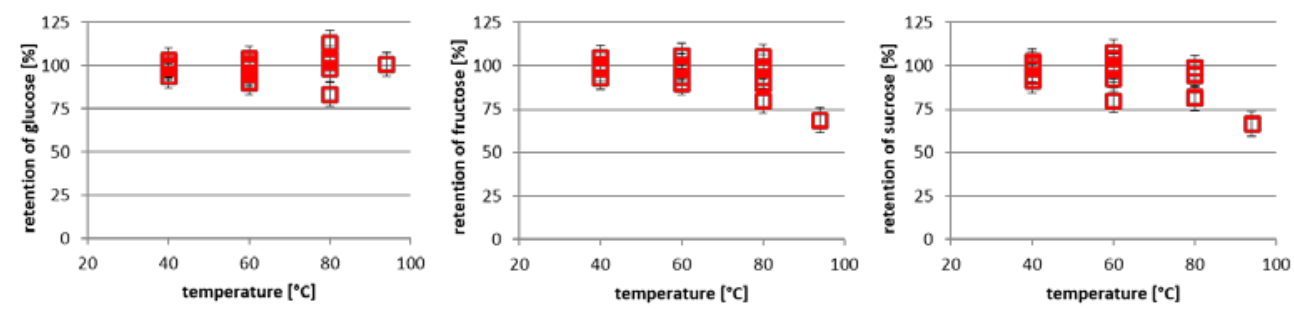

Fig. 3 Retention of sugar in mangoes

The contents of fructose (fig. 3, center) and sucrose (fig. 3, right) decrease as the drying temperatures increase. The content of glucose seems to be nearly independent of the drying temperature or increases slightly. This increase of glucose and at the same time degradation of sucrose is due to the fact that sucrose is a disaccharide consisting of two molecules: one fructose and one glucose [21]. During drying, it seems that sucrose divides back into its two constituting molecules. The rate at which the sucrose molecules split is higher at high drying temperatures, which in turn means that the contents of fructose and glucose increase. As shown in fig. 3, the content of glucose rises slightly with increasing drying temperature compared to fructose which decreases, because fructose and glucose are also degraded 
during drying. Nevertheless, the degradation especially for glucose seems to be muffled because of the continuous splitting of sucrose [16, 21].

The colour of the dried samples was also compared with the colour of the fresh fruit. For an easy comparison, the CIE $L^{*}, a^{*}, b^{*}$ colour space is used. $a^{*}$ represents the colour space from green to red; $b^{*}$ from blue to yellow and $L^{*}$ represents the brightness (white to black). The total colour difference $T C D$ is calculated out of these values using equation (1):

$$
T C D=\sqrt{\left(\Delta L^{*}\right)^{2} *\left(\Delta a^{*}\right)^{2} *\left(\Delta b^{*}\right)^{2}}
$$

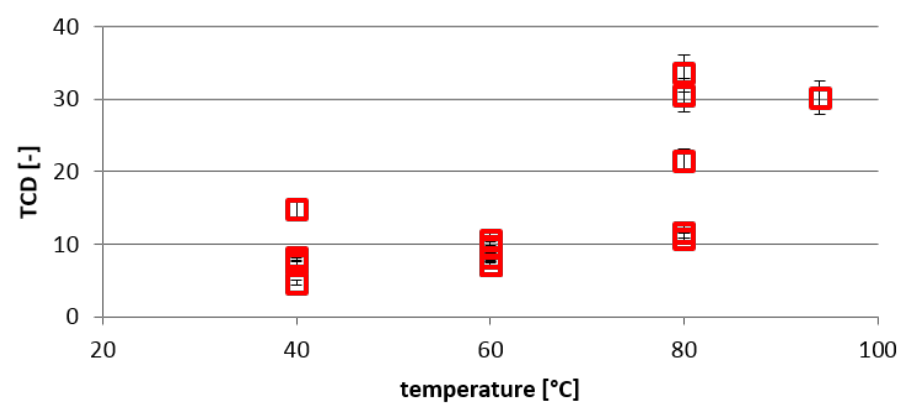

Fig. 4 Colour changes in mangoes

As it can be seen in fig. 4, the TCD increases as the drying temperatures increase. This is not only recognizable from fig. 4 , but also from fig. 5 , which shows, that the mango powder gets darker as the temperature increases.
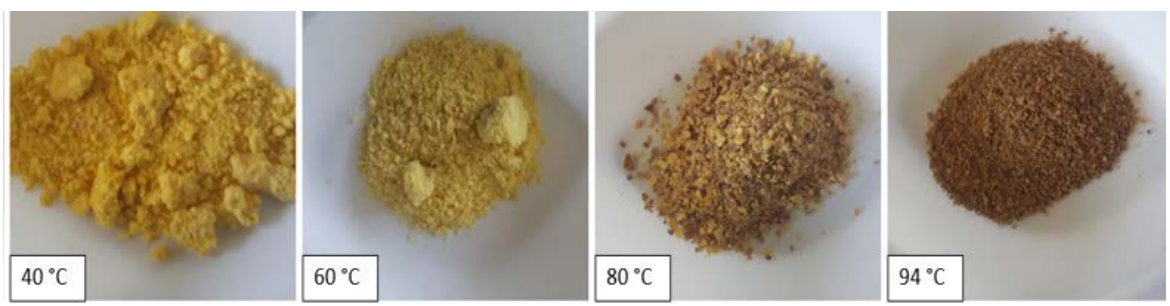

Fig. 5 Colour changes in mangoes (photo)

At last the retention of the surface area (shrinkage $S$ ) of mango samples before and after drying was compared. The retention of surface is calculated using equation (2), where $P_{0}$ and $P$ represent the amount of pixels before and after drying, respectively.

$$
\mathrm{S}=100-\left(\frac{\mathrm{P}}{\mathrm{P}_{0}} * 100\right)
$$

As it can be seen in fig. 6, the retention of the surface decreases as the drying temperatures increase. This is due to the fact that mangoes loose water during drying and become smaller. 


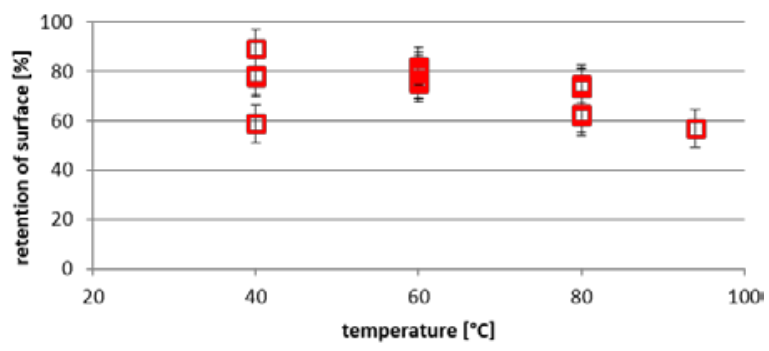

Fig. 6 Surface retention of mangoes

\section{Conclusions}

It can be concluded that the drying temperature has the largest influence on changing the quality criteria during the drying process of mangoes. The evaluation according to DoE revealed that dew point temperature as well as air velocity have a slight effect on the changing of the quality criteria. Furthermore, it was found that dew point temperature should be kept at $20^{\circ} \mathrm{C}$ and air velocity at $0.9 \mathrm{~m} / \mathrm{s}$. It could be shown that concentrations of ascorbic and citric acid in dried mangoes decrease with increasing drying temperatures. The content of malic acid as well as that of glucose seem to be nearly independent of the drying temperature. The contents of sucrose and fructose decreased during drying. The degradation of sucrose can be explained with the splitting of this molecule into fructose and glucose. Fructose seems to be more instable towards heat so it decreases more than glucose. This is due to the fact that sucrose consists of molecules of fructose and glucose and is divided into these two substances during drying $[16,21]$. An optimal air temperature for the drying of mangoes could be found at around $60^{\circ} \mathrm{C}$, because all of the mentioned components show a low or the lowest change/degradation values. The changes in the mentioned quality criteria should be kept as low as possible because organic acids as well as the different sugars are responsible for the taste of the mangoes and possesses health promoting qualities.

\section{Acknowledgements}

The underlying RELOAD-Project for this report is funded by the German Federal Ministry of Education and Research, grant number 031A247C. The responsibility for the content of this publication lies with the author.

\section{References}

[1] Priefer, C., Jörissen, J, Frisch auf den Müll - Verringerung der Lebensmittelverluste als Ansatz zur Verbesserung der Welternährung, Karlsruhe KIT, (2012)

[2] Maskan, M., Kinetics of colour change of kiwifruits during hot air and microwave drying, Journal of Food Engineering, 48, (2001), 169-175

[3] Arendt, S., Qualitätsuntersuchung an getrockneten Agrarprodukten, (2013), 55-57

[4] Franke, W., Nutzpflanzenkunde - Nutzbare Gewächse der gemäßigten Breiten, Subtropen und Tropen, Georg Thieme Verlag Stuttgart, New York, (1997) 
[5] Isler, O., Brubacher, G., Ghisla, S., Kräutler, B., Vitamine II, Wasserlösliche Vitamine, Georg Thieme Verlag Stuttgart, New York, (1988)

[6] Zeitler, S., Ascorbinsäure (Vitamin C), Available: http://daten.didaktikchemie.unibayreuth.de/umat/vitamin-c_1/vitamin-c.htm, [10.06.2013], (2003)

[7] Biesalski, H. K., Grimm, P., Taschenatlas Ernährung, Georg Thieme Verlag Stuttgart, New York, (2007)

[8] Santos, P. H. S., Silva, M. A., Retention of Vitamin C in Drying Processes of Fruits and Vegetables-A Review, Drying Technology, 26, (2008) 1421-1437

[9] Die Verbraucher Initiative e.V., zusatzstoffe-online.de - Informationen zu Lebensmittelzusatzstoffen, Available: http://www.zusatzstoffe-online.de/zusatzstoffe/113.e330_ citronens\%E4ure.html [18.04.2017], (2006)

[10] Verein für unabhängige Gesundheitsberatung Europa (UGB), UGB - Gesundheitsberatung unabhängig - kompetent - nachhaltig, Available: www.ugb.de/exklusiv/ fragen-service/ist-zitronensaeure-als-zusatzstoff-schaedlich/?zusatzstoff-zitronensaure, [05.08.2013], (2014)

[11] Onmeda - Für meine Gesundheit, Available: medikamente.onmeda.de/Wirkstoffe/ Natriumcitrat/wirkung-medikamente-10.html, [18.04.2017], (2007)

[12] Gaffron, F. Available: https://energy-drink-magazin.de/2013/03/apfelsaure-e29610549, [18.04.2016], (2013)

[13] Die Verbraucher Initiative e.V., zusatzstoffe-online.de - Informationen zu Lebensmittelzusatzstoffen, Available: http://www.zusatzstoffe-online.de/zusatzstoffe/9 2.e296_apfels\%E4ure.html, [18.04.2017], (2013)

[14] Internationale Normung von Obst und, Gemüse, Leitfaden zu objektiven Testmethoden zur Bestimmung der Qualität von Obst und Gemüse sowie Trocken- und getrockneten Erzeugnissen, Organisation for Economic Co-Operation and Development, (2005)

[15] Senser, F., Scherz, H., Kirchhoff, E., Lebensmitteltabelle für die Praxis, Der kleine Souci-Fachmann-Kraut, Deutsche Forschungsanstalt für Lebensmittelchemie: Wissenschaftliche Verlagsgesellschaft mbH Stuttgart, (2004)

[16] Ebermann, R., Elmadfa, I., Lehrbuch Lebensmittelchemie und Ernährung, Springer, Wien, (2011)

[17] Ramallo, L., Mascheroni, R., Quality evaluation of pineapple fruit during drying process, “ Food and Bioproducts Processing, 90, (2012), 275-283

[18] EUROPEAN STANDARD EN 14130, Lebensmittel - Bestimmung von Vitamin C mit HPLC, Brüssel, (2003)

[19] R-BIOPHARM AG (Roche), Sucrose/D-Glucose/D-Fructose UV method for the determination of sucrose, D-glucose and D-fructose in foodstuffs and other material, Darmstadt

[20] Metrohm AG, Das Säulenprogramm - Die ganze Welt der Ionenchromatographie, Herisau, (2011)

[21] Schwedt, G., Schreiber, J., Taschenatlas der Lebensmittelchemie, 2nd edition, WileyVCH, Weinheim, (2005) 